\title{
Spinal cord contusion and quadriplegia in a patient with Klippel-Feil anomaly
}

\author{
Amit Agrawal \\ Professor of Neurosurgery, Department of Neurosurgery, Narayana Medical College Hospital, \\ Chinthareddypalem, Nellore, Andhra Pradesh (India)
}

Key words: Cervical cord contusion, Klippel-Feil anomaly, minor trauma, KlippelFeil syndrome.

Klippel-Feil syndrome (KFS) patients are especially prone to cervical cord injury after a minor fall or a major traumatic episode. (1-9) A 43 year male patient presented with the history of road traffic accident. Following that he was unable to move all four limbs. He had urinary retention for which he was catheterized. Power in upper and lower limbs was grade 0/5. Deep tendon reflexes were absent. There was sensory loss below $\mathrm{C} 4$. Blood investigations were normal.

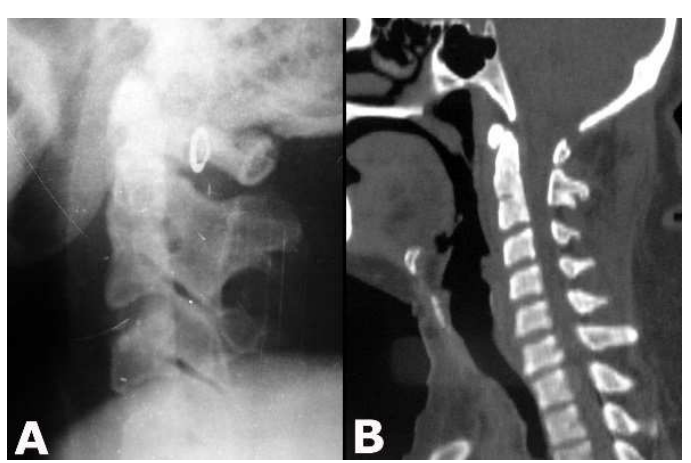

Figure 1 - (A) Lateral $x$-rays and (B) CT scan of the cervical spine showing C2-3 vertebral body fusion with waist formation

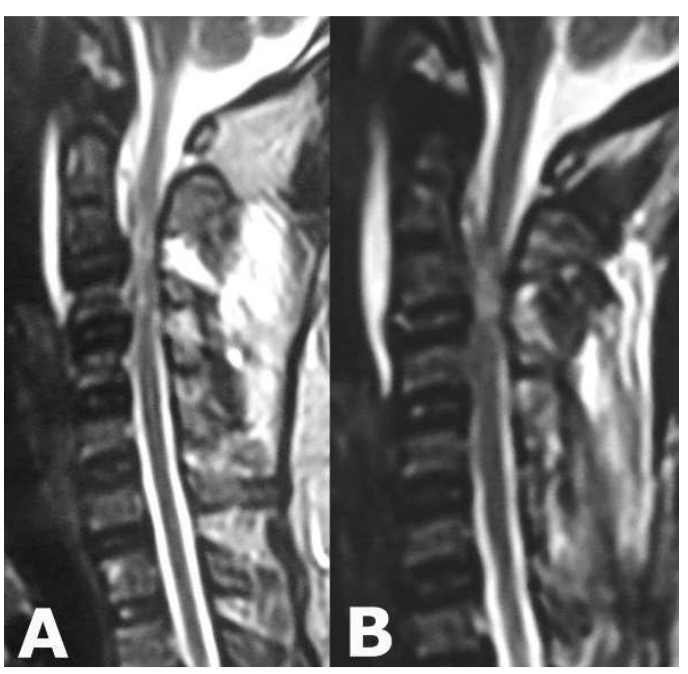

Figure 2 - Magnetic resonance image T2-weighted sagittal images showing a large contusion at C2-3 level in the spinal cord with canal stenosis and C3-4 disc prolapse causing the compression of the dural tube

X-ray cervical spine showed Klippel-Fiel of C2-3 (Figure 1). MRI showed cord contusion at C3-4 level with disc prolapsed (Figure 2). The patient underwent anterior cervical approach, cervical discectomy and fixation. $\mathrm{He}$ made minimal recovery in his motor power and was totally dependent for activities of daily living.

The marked deformities in KFS patients 
result in mechanical distortion altering the compensatory properties of the spine to react to decelerating and rotatory forces thus increase the probability of spinal cord injury with trauma. (4, 6-9) There is multiple mechanisms those make the patients more prone for injuries. There is an increase incidence of spondylotic and discogenic changes at the junctional segments resulting from hypermobile segments adjacent to the fused vertebrae leading to cervical instability. $(3-6,9,10,5)$ This can result in symptomatic herniated cervical disc with spinal cord injury. $(5,6,9,10)$ Apart from this there can be associated spinal canal stenosis, and, hence, increasing the likelihood to develop spinal cord injury in KFS patients even after minor trauma. $(6,11)$ Management of KFS patients with spinal cord injury depends on the severity of symptomatic segmental instability, presence or absence of disc prolapsed and associated neurological deficits. $(9,1213)$ In present case, the young adult patient had Klippel-Feil anomaly C2-3 segments, had disc prolapsed at C3-4 level level and canal stenosis at the fused segments made him prone for spinal cord injury even after trivial trauma.

\section{Correspondence:}

Dr Amit Agrawal

Professor of Neurosurgery

Department of Neurosurgery

Narayana Medical College Hospital

Chinthareddypalem

Nellore-524003

Andhra Pradesh (India)

Email-dramitagrawal@gmail.com dramit_in@yahoo.com

Mobile- +91-8096410032

\section{References}

1.Agrawal A, Badve AM, Swarnkar N, Sarda K. Disc prolapse and cord contusion in a case of Klippel-Feil syndrome following minor trauma. Indian journal of orthopaedics 2009;43:210-212.

2.HENSINGER RN, LANG JE, MACEWEN GD. KlippelFeil Syndrome A CONSTELLATION OF ASSOCIATED ANOMALIES. The Journal of Bone \& Joint Surgery 1974;56:1246-1253.

3.Guille JT, Miller A, Bowen JR, Forlin E, Caro PA. The natural history of Klippel-Feil syndrome: clinical, roentgenographic, and magnetic resonance imaging findings at adulthood. Journal of Pediatric Orthopaedics 1995; 15:617-626.

4.Karasick D, Schweitzer ME, Vaccaro AR. The traumatized cervical spine in Klippel-Feil syndrome: imaging features. AJR American journal of roentgenology 1998; 170:85-88.

5.Pizzutillo PD, Woods M, Nicholson L, MacEwen GD. Risk factors in Klippel-Feil syndrome. Spine 1994;19:2110-2116.

6.Vaidyanathan S, Hughes PL, Soni BM, Singh G, Sett P. Klippel-Feil syndrome-the risk of cervical spinal cord injury: A case report. BMC family practice 2002;3:6.

7.Matsumoto K, Wakahara K, Sumi H, Shimizu K. Central cord syndrome in patients with Klippel-Feil syndrome resulting from winter sports: report of 3 cases. Am J Sports Med 2006;34:1685-1689.

8.Strax TE, Baran E. Traumatic quadriplegia associated with Klippel-Feil syndrome: discussion and case reports. Archives of physical medicine and rehabilitation 1975;56:363-365.

9.Samartzis D, Lubicky JP, Herman J, Kalluri P, Shen FH. Symptomatic cervical disc herniation in a pediatric Klippel-Feil patient: the risk of neural injury associated with extensive congenitally fused vertebrae and a hypermobile segment. Spine 2006;31:E335-338.

10.Adeleye AO, Akinyemi RO. Cervical Klippel-Feil syndrome predisposing an elderly African man to central cord myelopathy following minor trauma. African health sciences 2010;10:302.

11.Prusick V, Samberg L, Wesolowski D. Klippel-Feil syndrome associated with spinal stenosis: a case report. Journal of bone and joint surgery American volume 1985;67:161-164.

12.Tracy M, Dormans J, Kusumi K. Klippel-Feil syndrome: clinical features and current understanding of etiology. Clinical orthopaedics and related research 2004;424:183-190.

13.Neroni M, Gazzeri R, Galarza M, Alfieri A. Intradural cervical disc herniation in a Klippel-Feil patient. Spine 2007;32:E608-E610. 